\title{
Hudnall-Pirtle Site: An Early Caddoan Mound Complex in Northeast Texas
}

James E. Burseth

Texas Historical Commission

Follow this and additional works at: https://scholarworks.sfasu.edu/ita

Part of the American Material Culture Commons, Archaeological Anthropology Commons, Environmental Studies Commons, Other American Studies Commons, Other Arts and Humanities Commons, Other History of Art, Architecture, and Archaeology Commons, and the United States History Commons

Tell us how this article helped you.

This Article is brought to you for free and open access by the Center for Regional Heritage Research at SFA ScholarWorks. It has been accepted for inclusion in Index of Texas Archaeology: Open Access Gray Literature from the Lone Star State by an authorized editor of SFA ScholarWorks. For more information, please contact cdsscholarworks@sfasu.edu. 


\section{Hudnall-Pirtle Site: An Early Caddoan Mound Complex in Northeast Texas}

Creative Commons License

(c) (i) (8)

This work is licensed under a Creative Commons Attribution-NonCommercial 4.0 International License 


\section{Hudnall-Pirtle Site: An Early Caddoan Mound Complex in Northeast Texas by James E. Bruseth Texas Historical Commission}

The Hudnall-Pirtle (41RK4) site is situated on a large T-1 alluvial terrace of the Sabine River in northern Rusk County of Texas (Figure 1). This part of Texas, commonly referred to as Northeast Texas, is part of the Southern Gulf Coastal Plain, a relatively level, sloping plain formed by prePleistocene embayments of the Gulf of Mexico. From a biogeographical perspective, the site is located in the Oak-Hickory-Pine Forest. This area represents the western extension of the Southern coniferous forests, and is dominated by shortleaf, longleaf, slash, and loblolly pine trees (Jordan, Bean, and Holmes 1984:28). In the floodplains of rivers and major creeks of Northeast Texas, the dominant vegetation is hardwood trees, including oak, hickory, elm, and gum. Soils consist of light colored to dark colored sands and sandy loams, with denser clays in the floodplains of major rivers and creek. The soils have been heavily leached by relatively high rainfall that ranges between 40 and 50 inches per year (Bomar 1983). Soils are generally acid, causing poor preservation of faunal remains in archeological deposits.

The first written description of the site is in an unpublished manuscript by amateur historian William Woldert from Tyler, Texas. In a section of the manuscript on old Indian trails, Woldert (1932) describes a "Mound Trail" that crossed the Sabine River in northern Rusk County and passed near a mound that almost certainly has to be part of the Hudnall-Pirtle site. He provides directions and distances to the mound from several surrounding towns, and plottings of these measurements correspond almost exactly with the Hudnall-Pirtle site.

In the 1930s, Hudnall-Pirtle site was recorded during a Works Progress Administration (WPA) sponsored archeological survey at the University of Texas (UT). A. M. Woosely of the WPA-UT program located the site based on information supplied by surrounding landowners, and recorded it as consisting of a "medium sized earth mound" (Woosley 1939). While notation of a single mound is perhaps understandable due to the heavy vegetation that likely covered the site at the time, almost certainly if he had spent any time walking over the area he would have noted the presence of several other earthen mounds. In many respects, though, it is fortunate that the site was recorded as only having a single mound. This put it into a class of sites for which there are numerous examples in Northeast Texas. If its true size and significance had been properly understood, almost certainly WPA-UT archeologists would have wanted to excavate the site. 


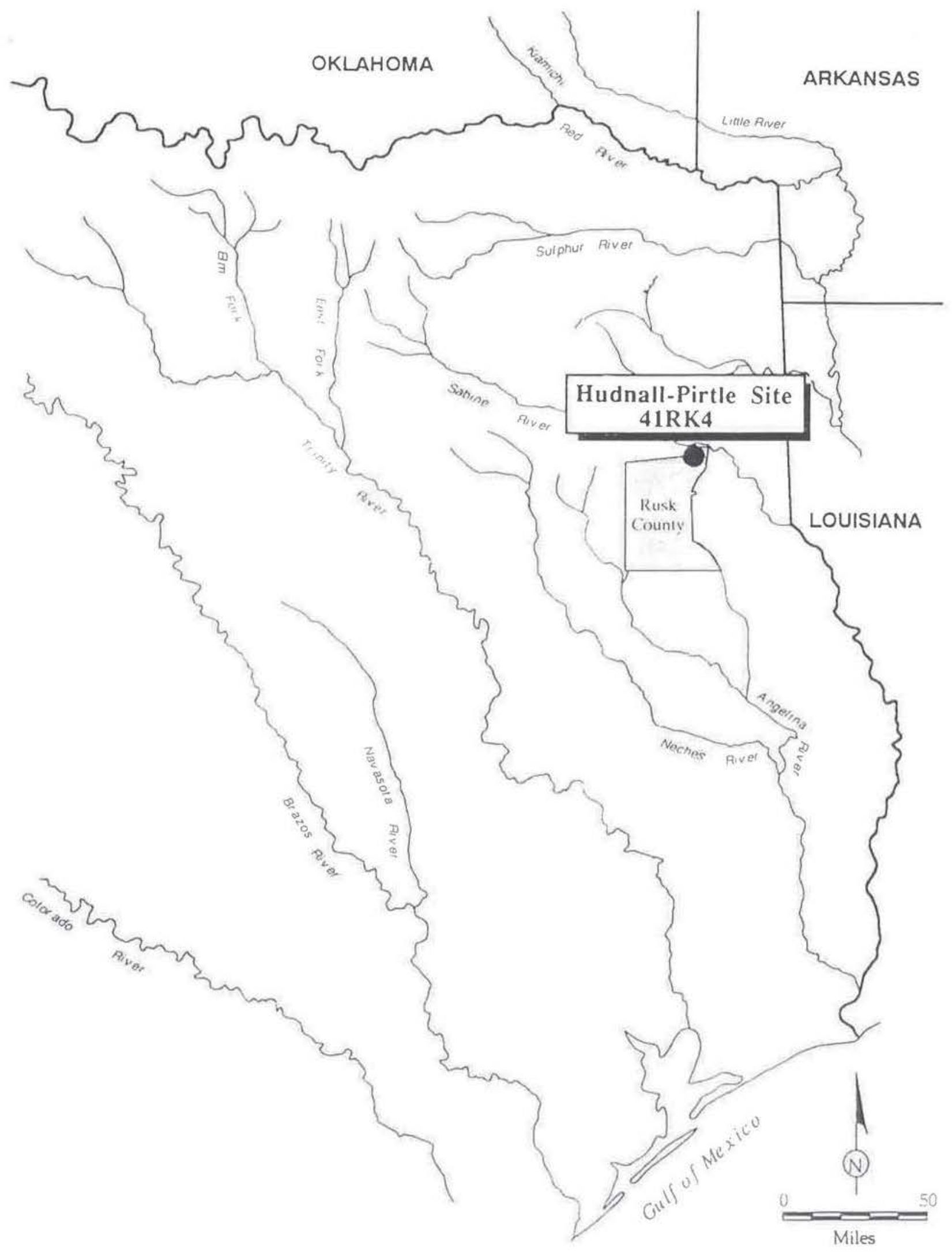

Figure 1. Map Showing Location of Hudnall-Pirtle Site in Rusk County, Northeast Texas. 
Given the relatively rudimentary techniques that were being used at this time, the site would likely have been excavated with little attention for note taking and with great emphasis on obtaining display quality artifacts.

The next mention of the site is in the published transcripts of the Seventh Caddo Conference held in 1963 (Davis, Wyckoff, and Holmes 1971:101). During a discussion of diagnostic artifacts traits from Early Caddoan Period sites, then amateur archeologist Calvin Jones presented the following information about the site:

...there is one big mound site (Bivins farm) located in the Sabine bottomlands of northeastern Rusk County. It is composed of five mounds arranged around a plaza; they consist of two large rectangular temple mounds and three large circular mounds. I would guess this site to be primarily of Alto origin although tests in the village area revealed Alto and Coles Creek sherds. (Davis, Wyckoff, and 1971:101)

Surprisingly, none of the other archeologists attending the conference followed up with questions or comments about this obviously major Caddoan mound center.

During the mid-1960s, Calvin Jones conducted archeological investigations at the site. Although none of these investigations have been reported, limited details on this effort are available from discussions with his mother, Mrs. Jones of Longview, Texas. Calvin appears to have spent much of his time working on what is labeled as Mound $\mathrm{C}$ on Figure 2. He dug an east-west trench across the entire mound. The width of the trench is not known, but based on the appearance of the mound today (the trenches were not backfilled), his trench must have been at least $1 \mathrm{~m}$ wide. A perpendicular trench oriented from the center of the mound to the south was also dug and appears to have been of equivalent width. According to Mrs. Jones, both trenches were dug to the bottom of the mound. The only artifact found was a "ceramic vessel with nodes on the exterior." Otherwise the mound consisted of sterile "sugar sand."

Calvin apparently concluded that the mound capped a sub-mound pit, likely a burial chamber, and decided that excavation needed to continue deeper. However, the unconsolidated sands of the mound caused the trench walls to cave in, and he decided it was not safe to continue the existing trenches deeper by hand. At this point, he enlisted the aid of Mr. Sam Whiteside from Tyler, Texas, to assist in the excavations. Mr. Whiteside owned a front-end loader and volunteered its use to help remove the mound fill and to expose the subsurface pit. The front-end loader was brought to within a mile of the site, at which time it began to rain. The rain was sufficiently great that the front-end loader could not continue to the site and was taken back to Mr. Whiteside's 


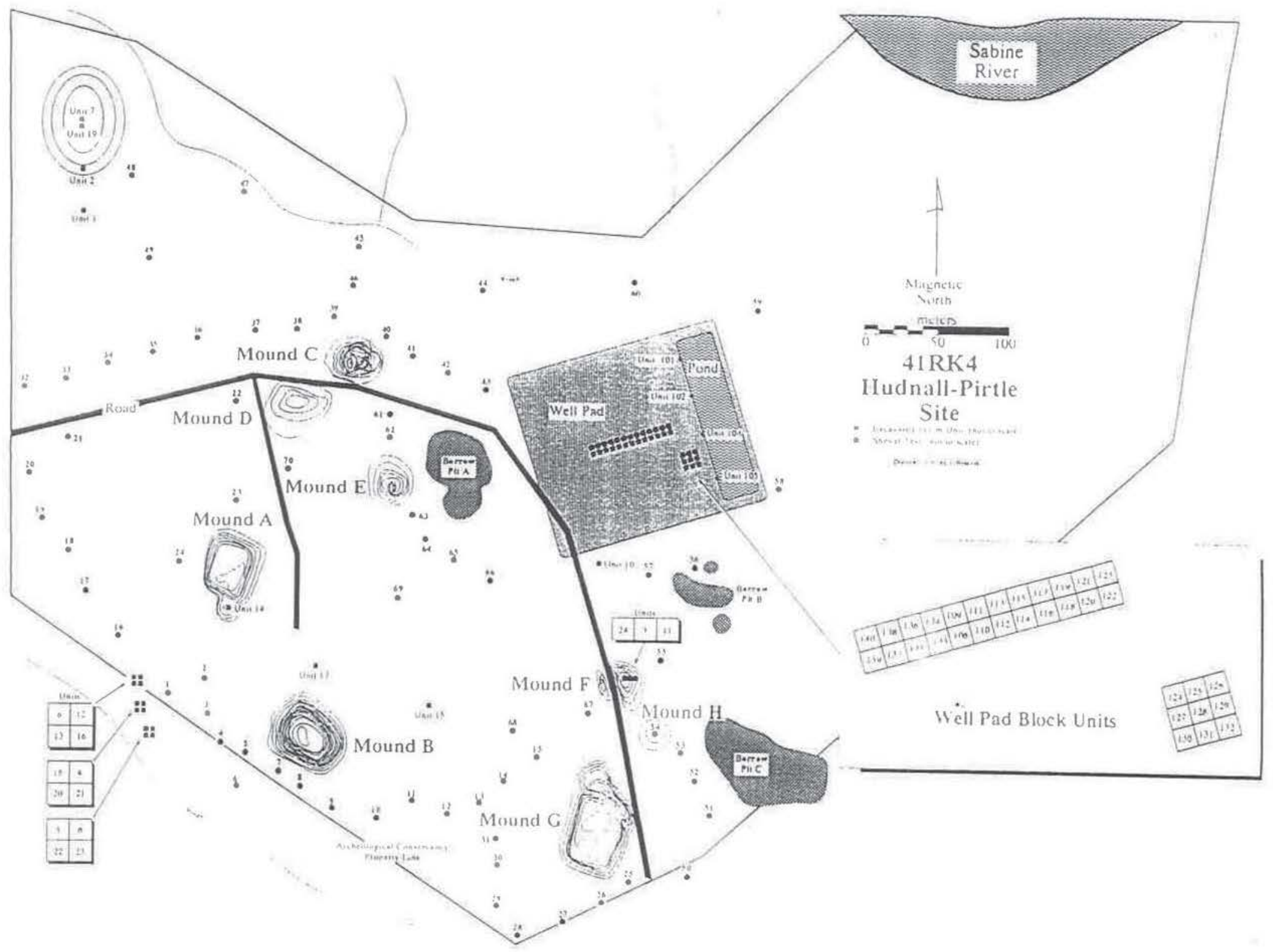

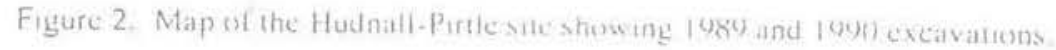


house. This activity was never attempted again, and the rain is responsible for preventing Mound $\mathrm{C}$ from being totally excavated.

The site was re-discovered by the author and Bob D. Skiles in the early 1980s based on the description given in the Seventh Caddo Conference transcripts. The site was located, visited, and re-recorded. A short time later, the author came into contact with the Archeological Conservancy, and explained the importance of the site and underscored the need to permanently preserve it. Under the guidance of the Conservancy's Southwest Regional Director, Mr. Jim Walker, the site was acquired in 1986 and is today an archeological preserve.

During 1989 and 1990 the Archeological Planning and Review Department of the Texas Historical Commission tested the site to gain a better understanding of its size and periods of use. Seven of the eight mounds were mapped (Mound $\mathrm{H}$ was found after the testing program had ended), shovel tests were conducted over much of the Conservancy's property, and several test investigations were conducted (see Figure 2). Two block excavations were placed in an area disturbed by recent oil drilling activity to sample the remaining deposits (Units 108-140). Unfortunately, the upper 30 $\mathrm{cm}$ of the deposits had been removed by the preparation of the well pad, and other deposits were totally removed by a pond constructed on the eastern edge of the pad.

This effort and additional block excavations placed in the southwestern portion of the site (Units 4$6,8,12,13,16,18,20-23$ ) encountered substantial preserved middens deposits. These areas contained several features including postholes, pit, and hearths. No complete posthole patterns could be identified, however, in the 45 square meters exposed in the village areas.

Limited work was conducted in two of the mounds. Excavations (Units 3, 11, and 24) in Mound F showed the presence of a burned, and likely dismantled, structure on the pre-mound surface. The structure was apparently capped with clay and sand while the burned timbers were still hot, as seen by the fire reddened quality of the clay in direct contact with the charred timbers. Two radiocarbon dates were obtained on charcoal from the timbers. These dates, calibrated according to Stuiver and Becker (1986), are A.D. $1158+/ 70$ and A.D. $1174+/-70$. The mound cap was $1.3 \mathrm{~m}$ in height. Mound A, located across the plaza from Mound F, was sampled by a single unit (14) placed in a small, conjoined mound. The mound was found to be 1.2 meters in height, and Early Caddoan Period village debris was located beneath it. The fill was sandy loam with no discemable stratigraphy, and the purpose of this part of Mound A is unknown. 
Two units (17 and 15) were placed in the plaza, and failed to recover more than a few flakes. This is in marked contrast to units in the well pad area and in village deposits southwest of the plaza where hundreds of artifacts were found in each unit.

Four units $(1,2,7$, and 19) were placed in what at the time was thought to be a man-made mound in the extreme northwestern corner of the Archeological Conservancy's property. This effort showed that occupation occurred over the surface of the mound, but that the mound itself was a natural terrace rise and not man-made.

Shovel testing was conducted across the site (see Figure 2) and was instrumental in defining the location of village deposits. Substantial numbers of artifacts occurred in virtually all shovel tests outside of and around the plaza. Nearly all portions of the Archeological Conservancy's property contain village deposits, mounds, or the plaza. There are two exception to this. The first is between Shovel Test 59 and the Sabine River (see Figure 2). This area is low and is covered by water during several months of the year; the site boundary ends about 10 meters northeast of Shovel Test 59. Second, a small portion of the site extends beyond the Conservancy's property on the southwest, between the property line and the slough shown on Figure 2. Otherwise, the Archeological Conservancy's property line delimits the site boundary.

It is apparent from the aforementioned evidence that the site served as a civic-ceremonial center and a village for a large resident population. Although shovel tests inside the plaza failed to show much artifactual evidence, work outside of the plaza showed occupation debris over much of the remainder of the site. The village area seems to have been located around the plaza and the mounds. The plaza appears to have been intentionally kept clean of trash, and most likely reserved for specialized activities. Limited testing in two of mounds indicates that one capped a structure and the other served an unknown purporse. It is likely that some of the other mounds may have served as burial tumuli for high status individuals, but this has not been confirmed by the testing program.

The excavations at the site confirmed Calvin Jones' assessment that it was occupied during the Early Caddoan period. Ceramics of types Pennington Punctated-Incised, Crockett Curvilinear Incised, Holly Fine Engraved, Weches Fingernail Impressed, Davis Incised, and Dunkin Incised were recovered. A few sherds of Coles Creek Incised, variety Coles Creek were also found suggesting an earlier occupation as well. Projectile points were almost exclusively the arrow types Alba, Bassett, Colbert, and Homan. A copper bead was found in the midden deposits in the southwest portion of the site. 
The artifacts and other information from the Texas Historical Commission's recent excavations are being analyzed by the author with the assistance of Timothy $\mathrm{K}$. Perttula. A report of the findings is expected to be completed during 1992 and will be published either as a journal article or a special publication of the Texas Historical Commission.

\section{References Cited}

\section{Bomar, George W.}

1983 Texas Weather. University of Texas Press, Austin.

Davis, Hester A., Don G. Wyckoff, and Mary A. Holmes (editors)

1971 Proceedings of the Seventh Caddo Conference. Oklahoma Archeological Survey, Occasional Publication No. 1. Norman.

Jordan, Terry G., John L. Bean, Jr., and William M. Holmes

1984 Texas: A Geography. Westview Press, Boulder.

Stuiver, Minze and Bernd Becker

1986 High-Precision Decadal Calibration of the Radiocarbon Time Scale, AD 1950-2500 BC. Radiocarbon Volume 28 (No. 2B), pp. 863-910.

Woldert, William Alber, Sr.

1932 East Texas. Unpublished manuscript on file at the Tyler Public Library, Tyler, Texas. Woosley, A.M.

1939 Notes on file at the Texas Archeological Reseach Laboratory, University of Texas. 